\title{
Consequences, Necessities and Advantages of Iran' Accession to the Statute of International Criminal Court
}

\author{
Behzad Dorraj $^{1}$, Dr. Abu Mohammad Asgarkhany ${ }^{2} \&$ Dr. Iraj Goldouzian ${ }^{3}$ \\ ${ }^{1} \mathrm{PhD}$ student, Department of Law, Qeshm Branch, Islamic Azad University, Qeshm, Iran \\ ${ }^{2}$ Faculty member of Tehran University, Department of Law, Tehran University, Tehran, Iran \\ ${ }^{3}$ Department of Law, Qeshm Branch, Islamic Azad University, Qeshm, Iran \\ Correspondence: Dr. Abu Mohammad Asgarkhany, Faculty member of Tehran University, Department of Law, \\ Tehran University, Tehran, Iran. E-mail: asgarkhany@yahoo.com
}

Received: July 4, 2016 Accepted: July 18, 2016 Online Published: July 31, 2016

doi:10.5539/jpl.v9n6p219 URL: http://dx.doi.org/10.5539/jpl.v9n6p219

\begin{abstract}
The existing conflicts between approval of Rome Statute by Islamic Consultative Assembly along with joining the International Criminal Court and national interests and some of Islamic laws and regulations, has always been a controversial issue among scholars of law community of Iran because of the establishment of International Criminal Court and signed the Rome Statute by Islamic Republic of Iran. Many believe that accession to the International Criminal Court and its approval by parliament is inconsistent with national interests and sovereignty and also would bring negative consequences to the country. Contrary to this view, it is believed that provisions of the Rome Statute are not inconsistent with Islamic and domestic regulations and this accession can bring positive outcomes and international interests to Iran. In this way, national power and sovereignty of country would be reinforced at international level. The present study has investigated positive consequences and advantages of Iran's accession to the Rome Statute.
\end{abstract}

Keywords: International Criminal Court, The Rome Statute, international crimes, accession to the Rome Statute, Security Council, The supplemental jurisdiction of the Court

\section{Introduction}

The statute of International Criminal Court was adopted on 17 July 1998 through decision making of national politics and international cooperation by deputies from different countries of the world in Rome. This statute was exposed to be signed by governments due to consideration of millions of sacrificed children, women and men in horrors and war crimes and troubled human conscience to punish perpetrators of such offenses and end their impunity and escape punishment (Ale Habib, 1999, Shareeat Bagheri, 2011). According to this status, the international court under the name of International Criminal Court that is related to the United Nation' system with jurisdiction over crimes committed by persons, intends to complement national criminal courts. States that have ratified this statute and also have acceded to the statute are committed to implementing the provisions of the law. They would recognize the jurisdiction of the court and the subject of the Statute of International Court. The mentioned states recognize the considered crimes in the Statute as a serious crime and would try to punish commitments. They recognize the Court's jurisdiction in the case of inability, unwillingness and negligence in implementation of provisions.

As of March 2011, 144 states had ratified and been parties to the statute. The Islamic Republic of Iran that had an active participation in related conferences to statute, especially Rome meeting, abstained then signed it with the support of the then head of the judiciary on the last day of statute' openness to be signed (31 December 2000). Iran has neither ratified nor acceded the statute. There have been many debates about Iran' accession to the Rome Statute and International Criminal Court. In this regard, some opinions present the necessity and advantages of Iran' membership to International Criminal Court and adoption of the Statute in Islamic Consultative Assembly. Many of law experts are against this matter also concerned about the consequences of membership of the Rome Statute and International Criminal Court. This paper has assessed the written legislation of the Islamic Republic of Iran and the regulations of International Criminal Court to investigate the advantages and necessities of the Iran' accession to the International Criminal Court and adoption of its Statute 
by Islamic Consultative Assembly. Therefore, it would be possible for researchers to evaluate these necessities and advantages regarding making a judgment about the opposed views (Ardebili, 2011, Mazaheri, 2013).

\section{Method}

Today, the international community is the inheritor of an established document including strengths and weaknesses that are manifested in International Criminal Court. It would be vital to know that existence of these strengths and weaknesses is a common issue since this document is obtained from political debates and dissections between 160 units with different legal and political motivations. Every state has ignored its power and interests to achieve a higher goal that is for the benefit of human society. Accordingly, it would be common to find conflicts between principles and beliefs of the Islamic Republic of Iran and some provisions of the Statute that can't be accepted by Iran. In one hand, it would be essential to investigate the advantages and disadvantages of accession or non-accession to the Statute in a consistent and expert method. On the contrary, the issue of accession to the Statute should be evaluated as a general matter based on its consequences (Deyhim, 2014). Some of the necessities and concerns (advantages and disadvantages) about the accession to the Statute have been presented in this study to consider a logical and master method. These benefits and cons can be mentioned as follows:

- Considering Court' regulations as customary rules

By the end of cold war and the creation of a hierarchical system in the world, there has been a greater sensitivity in international community towards the violation of international peace and security. Thus, the collective security system was fulfilled for the first time. Several tribunals have formed by Security Council to prosecute war criminals after identifying threats to the international peace and security under Chapter VII of the Charter. The issue of crimes against human peace and safety was considered in mentioned tribunals more sensitively. In this regard, if a country is committed crimes against social peace and security, it won't be away from international community's attention. Hence, the accession or non-accession to the International Criminal Court doesn't make any impunity even if a crime is within the framework of the national sovereignty of the considered country. By considering the legal nature of mentioned crimes, it could be found that many of the arrangements of the charter are the customary basis and considered as the jus cogens. These rules are entered into force for all the States regardless of their legal, political and cultural system.

- Non-accession as a political isolation

Non-accession to the Court could be considered as a political isolation. The issue of political isolation is combined with the allegations of human rights violation that are attributed to the Islamic Republic of Iran. The mentioned trend would make the allegations more considerable. Also, any postpone to the accession cause to lose some privileges including being a member of the assembly of states parties and participating in the introduction of judges and prosecutors and members of the Secretariat.

- The possibility of filling a complaint

According to Articles 13 and 14 of the Statute, all parties can refer their situation to the prosecutor. This situation may occur in states parties or other countries. Thus, it won't be any possible right to petition in International Criminal Court regarding international crimes if Iran is not a party to the statute. Being a member of the Court will make a right for states parties to file a lawsuit against nationals of other countries. The occurred events in recent years in neighboring countries of Iran (Iraq and Afghanistan) should be a good lesson for Iran. In this regard, William Schabas, the author of "An Introduction to the International Criminal Court" which last year had visited Iran says: "see your neighbor, Iraq in which all crimes within the jurisdiction of the Court have been happening over recent years. You can put British troops, Blair and Queen of England on trial in the International Criminal Court. I found Iraqi Foreign Minister in Netherland (2003) that was asked about Iraq's accession or non-accession to the Court. It had been so late, but I believed it was an essential to issue for Iraq to be a party to the Court. Therefore, the issue of Abu Gharib would be within the jurisdiction of the Court.

Hence, it would be vital for Iran to be a party to the Court before any circumstances happen. Concerning the situation in the region, Iran is less likely to commit these crimes while it is possible to be the victim of these crimes. 114 countries have been parties to the Court until 12 October 2010. Accordingly, any postpone to this trend means ignoring the supposed interests regarding referring to the Court.

- Participating in Court' affairs

That is a question whether there is any possible harm to Iran with being a party to the United Nations in which five members of Security Council have Veto power. There are some considered harms to Iran regarding accession to the United Nations, but it will bring some opportunities including presenting ideas in the presence 
of other states, taking advantages from like-minded countries, being useful in some international decisions even if the state is unable to effect on all decisions made by all parties. The prosecution would be in the same way in Court. Iran must be a member of the Court to be useful in international decisions. One of the most important reasons of Iran' accession to the Criminal Court is to choose an active policy and approach instead of a passive system. It has been proved by experiences that without being a member of the Court it won't be possible to have a great role in international games and defeat would be a certain result.

- Electing the judge of the Court

According to the Paragraph 4 of Article 36 of the Statute, each state party may put forward one candidate for any given election who need not necessarily be a national of that state party to choose judges. According to the Paragraph 8 of this Article, The States parties shall, in the selection of magistrates, consider the representation of the principal legal systems of the world and equitable geographical distribution. Therefore, with accession to the Court Iran can effect on the election of Muslim judges and even election of an Iranian judge. It is possible to response to the presented objections regarding referring to the non-Muslim judges from several perspectives:

First: some criteria have expressed to accept judges in religion. One of them is to be diligent in Islam. This particular and consensus condition has been ignored due to the scientific problems. In fact, the present judges are similar to the religious and jurisprudential diligent of judges. These judges are named permitted judges by the supreme leader or legal experts. Therefore, these legal experts or allowed judges don't have all religious and jurisprudential conditions of judgment in the current judicial system of Iran. Accordingly, there is no problem in the lack of some written conditions regarding analysis such as being male or being Muslim. It would be essential to have scientific competence in the fields of criminal law and criminal procedure to gain a judicial position in international law. If violation of the condition of jurisprudential judge is possible, there is no limitation in terms of ignoring other conditions.

Secondly: in past, Iran referred to the international judicial organizations like International Court of Justice through acceptance jurisdiction of foreign judgments organizations. Selected judge by Iran was a Belgium and non-Muslim judge in the case of oil platforms against American.

Thirdly: referring to the unbeliever judges at the Court can't be considered as a way of dominance for unbelievers Jurisprudential rule of dominance denial (nafy sabil). And depending on the tyrants (Jurisprudential rule of Rokun to Oppressor) based on the verse of "And incline not to those who do wrong", so Iran' accession to the Court is not prohibited. This accession is considered as a contract in which judges are elected in agreement of both sides, and all parties refer to the Court regarding occurred crimes and complementary jurisdiction. This situation doesn't consider as depending on unbelievers, and such contracts exist in Islam and jurisprudence.

\section{- $\quad$ The right to vote}

According to the statute of the Court, states parties have the right to vote in proposed affairs. Nevertheless, those countries that have signed the law but haven't accessed the Court can be present in Assembly of the State Parties as observers while state parties have a right to vote in the Assembly of the State Parties based on the Article 112. Hence, it is fixed issue for Iran to be a party to the Court to effect on the affairs.

- Knowing about the investigations

According to the Paragraph 1 of Article 18 of the Statute of International Criminal Court, when a situation has been referred to the Court under Article 13 (a), and the Prosecutor has determined that there would be a reasonable basis to commence an investigation the Prosecutor shall notify all States Parties even limitedly. This privilege is not considered for non-member countries and telling these States is concerned to exercise jurisdiction over the crimes based on the available information.

- Protesting against decisions made by Court

If the prosecutor announces the admissibility of a complaint due to lack of legal basis under the Article 17 or if the attorney issues non-proceeding prosecution due to the lack of justice basis of an investigation under the Article 53(b), a state party referring a situation to the court (under the Article 14 of the Statute) will be able to appeal the prohibition of prosecution in a permanent institution (under the paragraph 3 of Article 53 of the statute). Nonparty state nor can refer a case to the Court neither can request to appeal the prohibition of prosecution. According to the paragraph 2 of Article 52, only states parties can complain about rules of procedures and any adopted evidence and amendments of the Court.

\section{- Cooperation request}

States parties can request cooperating with the Court. The Court may, upon request, cooperate with and provide 
assistance to a State Party conducting an investigation into or trial in respect of conduct which constitutes a crime within the jurisdiction of the Court or which constitutes a serious crime under the national law of the requesting State. According to the paragraph 10 of the Article 93 of the Statute, this assistance shall include the transmission of statements, documents or other types of evidence obtained in the course of an investigation or a trial conducted by the Court and the questioning of any person detained by order of the Court in which nonparties states have no right in this matter.

- Non acceptance of amendments

According to the paragraph 3 of Article 121 of the Statute, the adoption of an amendment at a meeting of the Assembly of States Parties or at a Review Conference on which consensus cannot be reached shall require a two-thirds majority of States Parties. Hence, Iran can prevent some adoptions of amendments that are against its interests through consulting with other parties. The most important and vital changes include in Articles 5, 6, 7 and 8 of the Statute that describe all crimes in jurisdiction of the Court. According to Paragraph 5 of Article 121, if any amendment occurs in the Statute and a state party doesn't accept the amendment, the court won't exercise its jurisdiction regarding amendment cases. If an amendment has not been accepted by States Parties by paragraph 6 of Article 121, any State Party, which has not accepted the amendment might withdraw from this Statute with immediate effect. Notwithstanding Article 127, paragraph 1, by giving notice no later than one year after the entry into force of such amendment.

- Complementary jurisdiction of the Court

According to the statute of the International Criminal Court, jurisdiction of the Court is intended to complement the national criminal jurisdictions. This issue has been considered in Articles 1 and 17 of the Statute. According to Paragraph 1 of Article 17 of the Statute, the Court shall determine that a case is inadmissible where the case is being investigated or prosecuted by a State which has jurisdiction over it. Therefore, there is not any interference from the Court if domestic judicial system of Iran is able to handle the international crimes. Thus, all criticism about this matter would be removed. Of course, the court can recognize the ability or willingness of the state to handle crimes. It would be possible to put the criminals in trail in domestic judicial systems through deduction of legal regulations. Thus, accession to the Court brings complementary jurisdiction as an advantage for parties.

\section{- No violation of national sovereignty}

An absolute sovereignty would not be accepted by any conscience and human in order to have right to exceed another country without any question. The concept of the freedom has been changed a lot since 19th century. Thanks to the present concept of sovereignty, there are kinds of international adoptions and different conventions regarding human rights and useful disarmament. Traditional concept of the freedom has destroyed through the creation of the International Criminal Court, accession of 114 states to the Court till 12 October 2010, handling four cases and international arrest warrant. The present international system would conduct the cases through the new interpretation of sovereignty concept. Delegation of the jurisdiction over the international crimes under the condition of the initial commitments and willingness of the states not only is the concept of sovereignty but is accepted in order to gain more perfect advantages including the news peccary of punishment of international criminals (Mirmohammad Sadeghi, 2009, Mousazade, 2011). The agreement between Prophet Muhammad and disbelievers of Medina can be a good example from the history of Islam. The Prophet agreed with disbelievers one year Muslims go to the pilgrimage and the other year it was disbelievers' turn to go. Thanks to this agreement, the pilgrimage was not closed. For instance, under some conditions the pilgrimage was sanctioned by the command of Imam Khomeini. Hence, the mentioned issues that cause the presence of the country (Iran) in international assemblies are not considered as a violation of national sovereignty. In can be eventuated that Iran' non-accession to the court can lead to the violation of national sovereignty.

- No advantages in non-accession to the Statute

The question is not about the consequences of the Iran' accession to the Court but the basic question is about if there is any practical difference in non-accession of Iran. The response would be not. Iran' accession or non-accession to the Court won't make a difference in the issue. The Court continues to pursue its goal with presence of 114 states parties and effects on Iran willingly or unwillingly.

- Case referral by the Security Council

According to the Article 3, Security Council can refer a situation to the prosecutor according to the chapter 7 of the UN Charter. In this regard, the exercising of the jurisdiction is not dependent to be a party to the Court since the Court would exercise its jurisdiction over crimes. It is expected to refer the nuclear case of Iran according to the combination of Security Council and its performance. For instance, Security Council referred the situation of 
the Darfur region of Sudan to the Court in 31 March 2005 based on the chapter 7 of the Charter and Article 132 of the Statute. This case is being proceeding at the Court.

- The possibility of establishing special tribunals

According to the chapter 7 of the UN Charter, the Security Council can hold special tribunals in order to punish the international crimes threatening the world peace and security. The Statute of the International Criminal Court entered to the force to prosecute individuals for the international crimes of genocide, crimes against humanity and other crimes in 25 May 1993 in Yugoslavia and Rwanda. The Security Council has right to hold especial tribunals although the International Criminal Court is a permanent court prosecuting referral cases by the Security Council. Therefore, the possibility of constitution a tribunal against Iran may exist through more commitments (Mohammad Nasl, 2011). Hence, it would be acceptable that Iran' non-accession to the court won't any immunity or privileges to the country.

\section{Results}

According to the rules and regulations of Islamic Republic of Iran, Islamic system and jurisprudential regulations, some consequences as follows:

- The jurisprudential rule of dominance denial (Nafy Sabil) is a well-known regulation between jurisprudents, but its evidence is not strong enough. Based on this rule, jurisprudential regulations are divided into two categories as follows: regulations that are based on the mentioned rule and regulations that are confirmed by the state of dominance denial. There are no debates on rules established by the rule of dominance denial, and these regulations are mentioned by the jurisprudents while there are more dissections regarding laws that are only related to the state of dominance denial.

- The most considerable reason for this regulation is the Surat An-Nisa': "No merit is there in much of their private conversation, except for those who enjoin kindness or that which is true or conciliation among people. And whoever does that hunting means to the approval of Allah - then we are going to give him a high reward". As it was mentioned, the jurisprudential interpretation about this verse would be possible according to the general context of the verse. It would be essential to deny all the other contexts except legislative and formative ones. In fact, jurisprudential interpretation is a part of the general understanding of the mentioned verse (Mehra, 2011, Mohammadi, 1995). A part of the general description is to lack proficiency of unbelievers on Muslims. This claim is against the various narratives and verses of Quran due to the dominance of the unbelievers on the Muslims and also some Prophets and Imams have murdered by infidels. Therefore, the context of the verse is not assignable, and the meaning of that can't be generalized. According to the correct narrative quoted by Imam Reza, the sense of virtual way has denied from the verse and the present meaning in the poem has described as denying the arguments and evidence of infidels. It is stated that most of the old interpreters had accepted this interpretation of the verse. Another evidence for this rule is a talk "Islam prevails, not be against it" that is not predictable regarding jurisprudence due to existed weaknesses and ambiguities in it.

- Considering the weak evidence of the mentioned rule, the rule of dominance denial can't be an appropriate base to express the religious command and its instances. Thus, there are no limitations to Iran' accession to the International Criminal Court.

- Iran' accession to the International Criminal Court is not prohibited even if the rule of the dominance denial is accepted. Because the acceptance of a principle of a rule is different with acceptance of meaning such a dominance denial.

- The expressed objections toward Iran's accession to the Court are not acceptable. For instance, the prohibition of electing an unbeliever judge is mentioned while the religious conditions of a judge such as diligence are not considered in Iran. The present judges that are legal and permitted judges don't have necessarily religious conditions such as faith and being male while are permitted to perform and resolve issues based on the will of Iran to be party to the Court. Other objections can be removed based on the voluntary accession of Iran to the court to gain a significant benefit that is accepted in Islam such as punishment of international criminals and to prevent them escape from justice.

- Choosing active policy instead of passive policy is the most significant reason of Iran' accession to the Court. Being inactive behind the closed doors can't solve any problem and makes Iran ineffective in procedure of the Court. In this way, Iran wouldn't be able to participate in Court' activities. Iranian Muslim judges wouldn't be introduced to the Court, Iran won't have any right to vote and there would 
be an eternal fear in terms of being in a tribunal to be under the exercising jurisdiction by the Court instead of reinforcing its legal system and enjoying the optimal conditions of complementary jurisdiction of the Court.

- Also, non-accession to the Court won't make any secure margin for the country because regulations of the court have been changed to the conventional rules that are required to obey. On the other hand, Security Council can refer a situation to the Court based on Chapter 7 of the Charter or to hold a specific tribunal such as the former Yugoslavia and Rwanda.

- In short, the goals of the International Criminal Court are relatively adjusted with ideals of Islam and Islamic Republic of Iran. It would be possible to adequately organize some points in the procedure of the Court through accession and consultation with friend countries. Therefore, agreement to the Court is not considered as unbelievers' dominance over Muslims. Ignoring the existed objections in the rule of dominance denial, there wouldn't be any good point in non-accession to the Court. With more intensive study, Iran' non-accession to the Court can be considered as an example of the unbelievers' dominance over Muslims.

- As a result, the rule of the dominance denial is not a firm jurisprudential basis to issue a jurisprudential rule. Accordingly, Iran' accession to the Court is not considered as a way of dominance of unbelievers over Muslims even if the rule of the dominance denial is accepted. Hence, not only Iran' accession to the Court is unforbidden but is necessary too.

\section{Conclusion}

The necessity of criminalization and the definitions of crimes' basis and components are mentioned in Articles 1 and 17 of the Statute of the International Criminal Court. These components are required to obey by legal system. It would be essential to adjust domestic rules and regulations with written criminalization basis in the Statute of the International Criminal Court. This issue would express the consequences of the Iran' accession to the Court regarding quad crimes mentioned in the Statute. Accordingly, it would be necessary for states parties to prepare their national regulations regarding form and nature to implement expressed commitments and regulations of the Statute of the Court. Implementing regulations of the Statute includes several aspects related to the power and determination in prosecution and criminalization regarding written criminals in Statute of the International Criminal Court to benefit from advantages of the complementary jurisdiction of the Court. According to the criminalization' effects and definition of the war criminals' in the Statute, it would be vital to consider two categories of war crimes including international armed conflicts and committed war crimes in internal conflicts that are not precedent in international law.

Iran is a member of the four Geneva conventions while is not a party to the additional protocols of conventions. Iran' accession to the Statute regarding two categories of war criminals makes the country joins to the other protocols 1 and 2 of Geneva Conventions and implement its commitments. However, non-accession to the Court won't make the country irresponsible for violating commitments regarding mentioned crimes.

According to the Articles 4 and 5 of the convection and Iran's commitment to prosecute the crime of genocide regarding criminalization and definition of components of genocide, there is no problem in Iran' accession to the Court.

Legal system of Iran is faced two options in terms of criminalization and definition of crimes against humanity. There would be some obstacles in these two options. These options can be mentioned as follows:

1) Observation of the Statute's criteria and criminalization by considered conditions of the Statute regarding the crimes against humanity. These criteria are accepted by the Court while can be against the interests of the country.

2) Consideration of religious standards and rules that are mentioned in Islamic criminal law and adopting considered crimes against humanity with existed crimes in domestic standards. In this regard, it would be ness peccary to obey specified regulations and criteria in the Statute regarding new criminalization.

It can be found that selecting the second option not only is logical and beneficial but can prosecute crimes against humanity. However, there are some problems in this option including existence torture and cruel acts to prosecute crimes against humanity. Nevertheless, this option includes advantages since these punishments are not systematic and extensive.

Implementing the written punishments in the Statute should not encounter any problem although they include a range of financial sanctions and penalties depriving freedom. It would be essential to consider the Article 80 of 
the Statute: "Nothing in this Part affects the application by States of penalties prescribed by their national law, nor the law of States which do not provide for penalties prescribed in this Part.". However, this Article confirms all kinds of penalties and applicable methods of punishments inside the country but doesn't agree with all them. Some of these punishments may be considered as examples of tortures and crimes against humanity. Non-accession of Iran to the Court can't remove international responsibility regarding prosecuting crimes. Iran as a member of the Universal Declaration of Human Rights and the Covenant on Civil and Political Rights has recognized these prohibitions. From the view of customary international law, accession or non-accession can't effect on judgments of the international law organizations. In this respect, it is stated in the Article 21 of the Statute that the application and interpretation of law pursuant must be consistent with internationally recognized human rights. It would be possible at the Court to put a person on the tribunal under the claim of a systematic torture without Iran's accession to the Court. Despite the existence of the mentioned conventional prohibition, this issue (traditional prohibition) does not seem to be done simply in presence of limitations.

\section{References}

Ale Habib, E. (1999). International Criminal Court and Islamic Republic of Iran. Printing \& Publishing center of the Ministry of Foreign Affairs.

Ardebili, M. (2011). International criminal law, selected Articles. Mizan Pub, Tehran.

Deyhim, A. (2014). Assessment of international criminal law based on the Satute of International Criminal Court. Political and International Studies Office, Tehran.

Mazaheri, A. (2012). The principle of complementary jurisdiction of the International Criminal Court. Mizan Pub, 1, 213-224.

Mehra, N. (2011). International criminal law. Journal of the Process of Theories and perspectives, 1, 20-25.

Mirmohammad Sadeghi, H. (2009). International Criminal Court. Entesharat Pub, 5, 45-57.

Mohammad Nasl, G. (2011). The provisions of the International Criminal Court. Dadgostar Pub, 2, 310-316.

Mohammadi, A. (1995). The principles of Islamic law. Nashr Ney Pub, Tehran.

Mousazade, R., \& Aminian, A. (2011). Islamic Republic of Iran and International Criminal Court. Pardis Javan Pub.

Shareeat Bagheri, M. (2011). International criminal law. Jangal Javedane Pub.

\section{Copyrights}

Copyright for this article is retained by the author(s), with first publication rights granted to the journal.

This is an open-access article distributed under the terms and conditions of the Creative Commons Attribution license (http://creativecommons.org/licenses/by/4.0/). 